ISSN 0258-7122

Bangladesh J. Agril. Res. 38(4): 625-635, December 2013

\title{
ASSESSMENT OF SOIL CARBON STOCK OF SOME SELECTED AGROECOLOGICAL ZONES OF BANGLADESH
}

\author{
P. K. SAHA ${ }^{1}$, M. S. RAHMAN ${ }^{2}$, M. KHATUN ${ }^{2}$ \\ A. T. M. S. HOSSAIN ${ }^{3}$ AND M. A. SALEQUE ${ }^{1}$
}

\begin{abstract}
The present investigation assessed the soil organic carbon (SOC) stocks of four AEZs in Bangladesh which included AEZ 1 (Old Himalayan Piedmont Plain), AEZ 3 (Tista Meander Floodplain), AEZ 4 (Karatoya-Bangali Floodplain), and AEZ 9 (Old Brahmaputra Floodplain). Three land types - high land (HL), medium high and (MHL) and low and (LL) - were considered in the SOC assessment. The SOC stock was estimated by multiplying SOC (\%) with bulk density (g/cc) and soil depth (cm). Across the AEZs and land types, the SOC (\%) decreased with the increase in soil depth. The SOC (\%) was the highest in the low land and the lowest in the high land over the AEZs. The soil bulk density in every AEZ increased with soil depth. Bulk density of soil for medium high and varied from $1.26 \mathrm{~g} / \mathrm{cc}$ to $1.67 \mathrm{~g} / \mathrm{cc}$, for high and from $1.33 \mathrm{~g} / \mathrm{cc}$ to $1.55 \mathrm{~g} / \mathrm{cc}$, and for low land it was $1.13 \mathrm{~g} / \mathrm{cc}$ to $1.44 \mathrm{~g} / \mathrm{cc}$. The SOC stock at $0-20 \mathrm{~cm}$ depth was higher (14.19-4.67 t/ha) in low land followed by medium high land (8.25-4.58 t/ha) and high land (6.46-3.39 t/ha) for all AEZs. Among the four AEZs, the highest SOC stock was found in AEZ 1 irrespective of land types.
\end{abstract}

Keywords: SOC stock, bulk density, agroecological zones, land types.

\section{Introduction}

Crop production of Bangladesh appears to be vulnerable to climate change. Therefore, the food security is at risk. Some agronomic manipulation in the cropping systems and their management practices are needed to address this issue. The soil contains carbon in the organic as well as in the inorganic form. Soil organic carbon is mainly present in the soil organic matter in the form of C. and its availability in any soil mainly depends upon the kind of soil, its texture, vegetation and management processes. Management of SOC is very important for the maintenance of healthy soils because its loss leads to soil infertility. SOC can be helpful in mitigating the effects of elevated $\mathrm{CO}_{2}$ in the atmosphere, because change in land management practices can be helpful in sequestering the $\mathrm{C}$ from the atmosphere. Carbon sequestration reflects the longterm balance between additions of organic $\mathrm{C}$ from different sources and its losses from soil. Following the adoption of large-scale intensive cropping, with the introduction of modern varieties and increased use of chemical fertilizers, this

${ }^{1}$ Principal Scientific Officer, Soil Science Division, Bangladesh Rice Research Institute (BRRI), Gazipur-1701, ${ }^{2}$ Scientific Officer (Project), Soil Science Division, BRRI, Gazipur-1701, ${ }^{3}$ Senior Scientific Officer, Soil Science Division, BRRI, Gazipur-1701, Bangladesh. 
long-term balance has been modified. Intensive cropping encourages oxidative losses of C due to continued soil disturbance (Reicosky and Lindstrom, 1993) and it also leads to a large-scale addition of $\mathrm{C}$ to the soil through crop residues. Increase of SOC storage in crop land improves soil productivity and healthy environment ( $\mathrm{Lal}, 2004)$. The $\mathrm{C}$ stock would be either a net buildup or a net depletion. (Cole et al., 1993; Kong et al., 2005). Information of soil carbon balance in the major cropping patterns under different AEZs of Bangladesh is not well documented. Considering the above points, the present study was undertaken to document existing carbon stock in soils of four selected AEZs of Bangladesh.

\section{Materials and Method}

The study was conducted by the Soil Science Division, Bangladesh Rice Research Institute (BRRI), Gazipur during the period of 2010-11. The soil samples were collected from four AEZs: AEZ 1. Old Himalayan Piedmont Plain, AEZ 3. Tista Meander Flood Plain, AEZ 4. Karatoya-Bangali Flood Plain and AEZ 9. Old Brahmaputra Flood Plain.

Two upazilas of a district under each AEZ were selected for soil collection. The upazilas were Haripur and Ranisonkail of Thakurgaon district under AEZ-1, Rangpur Sadar and Pirgachha of Rangpur district under AEZ-3, Sajahanpur and Dhunat of Bogra district under AEZ-4 and Sarishabari and Jamalpur Sadar of Jamalpur district under AEZ-9. From one upazila, three villages were considered for soil sample collection. Soil samples were collected based on land types (high land (HL), medium high land (MHL), and low land (LL) and major cropping pattern in each of the four AEZs. Global Positioning System (GPS) reading was taken in each and every location of sample collection. Major cropping patterns were rice- fallow -rice, rice-non-rice-fallow and fallow-fallow-rice. A total of 960 soil samples were collected from four AEZs (240 samples from each AEZ) following the described sample collection protocol: two upazilas/AEZ, three villages/upazila, 10 sampling spots/village, 4 samples/spot. From each sampling spot, soil samples were collected considering 4 soil depths (0-5, 5-10, 10-15, and $15-20 \mathrm{~cm})$. Soil samples were analyzed for organic carbon by wet oxidation method (Walkley and Black, 1934). Bulk density $\left(\mathrm{g} / \mathrm{cm}^{3}\right)$ was determined by core sampler method (Blake and Hartge, 1986) considering 4 soil depths (0-5, 5-10, 10-15, and 15-20 cm) under different land types (High land, medium high land and low land). The Carbon stock (t/ha) in soils were calculated by using the following equation (Komatsuzaki and Syuaib, 2009):

Carbon stock $(\mathrm{t} / \mathrm{ha})=$ organic carbon content $(\%) \times$ bulk density $\left(\mathrm{g} / \mathrm{cm}^{3}\right) \times$ soil depth (cm). 


\section{Location and short description of the studied AEZs}

AEZ 1: Old Himalayan Piedmont Plain

AEZ 1 is located at most of Panchagarh and Thakurgaon districts and northwestern parts of Dinajpur district and the total area is $3982 \mathrm{~km}^{2}$ (398154 ha). Major land types are high land (58\%), medium high land (34\%), medium low land (1\%) and homestead + water (7\%) (Table 1). The soil texture is sandy-loam.

\section{AEZ 3. Tista Meander Flood Plain}

AEZ 3 is located at most of greater Rangpur, eastern part of Panchagarh and Dinajpur, Northern Bogra and part of Joypurhat, Naogaon and Rajshahi districts and the total area is $9468 \mathrm{~km}^{2}$ (946803 ha). Major land types are high land (35\%), medium high land (51\%), medium low land (4\%), low land (1\%) and homestead + water (7\%) (Table 1). The soil texture is loamy.

Table 1. Land type distribution among different AEZs.

\begin{tabular}{l|l|l|l|l|l|l|l|l|l|l}
\hline \multirow{2}{*}{ AEZ } & \multicolumn{5}{c|}{ Area (ha) } & \multicolumn{5}{c}{ Percentage (\%) } \\
\cline { 2 - 11 } & HL & MHL & MLL & LL & VLL & HL & MHL & MLL & LL & VLL \\
\hline 1 & 230,929 & 135,372 & 3,982 & -- & 58 & 34 & 1 & -- & -- \\
3 & 331,381 & 482,870 & 37,872 & 9,468 & 35 & 51 & 4 & 1 & \\
4 & 59,146 & 113,150 & 36,002 & 2,572 & 23 & 44 & 14 & 1 \\
9 & 202,450 & 253,063 & 144,607 & 50,613 & 28 & 35 & 20 & 7 & \\
\hline
\end{tabular}

AEZ 4: Karatoya-Bangali Floodplain

AEZ 4 is located at eastern half of Bogra district and most of Sirajgonj district and the total area is $2572 \mathrm{~km}^{2}$ (257158 ha). Major land types are high land (23\%), medium high land (44\%), medium low land (14\%), low land (1\%) and homestead + water $(14 \%)$ (Table 1$)$. The soil texture is silty loam and silty clay loam.

\section{AEZ 9: Old Brahmaputra Floodplain}

AEZ 9 is located at large areas in Sherpur, Jamalpur, Tangail, Mymensingh, Netrokona, Kishoreganj, Narsingdi, and Narayanganj districts. Small areas in the east of Dhaka and Gazipur districts and the total area is $7230 \mathrm{~km}^{2}$ (723037 ha). Major land types are high land (28\%), medium high land (35\%), medium low land (20\%), low land (7\%) and homestead + water (10\%) (Table 1). The soil texture is silty loam. 


\section{Results and Discussion}

\section{Soil organic carbon (SOC)}

The SOC\% for different AEZs is shown in Fig. 1.

\section{AEZ 1: Old Himalayan Piedmont Plain}

The SOC content (\%) in high land was low (1.04\% to $0.74 \%)$, in medium high land it was medium to low (1.41\% to $0.90 \%)$ and that in low land was high to medium (2.30\% to $1.87 \%$ ), as per SOC ranking outlined in FRG-2005 (BARC, 2005). It was observed that the SOC content (\%) decreased with increasing of soil depths irrespective of land types (Fig. 1 A). However, the SOC content (\%) in low land was higher than that in high and medium high lands.

\section{AEZ. 3. Tista Meander Floodplain}

The SOC content (\%) in high land was low to very low $(0.70 \%$ to $0.36 \%)$ in medium high land it was medium to low (1.20\% to $0.57 \%)$ and in low land was medium to low (1.39\% to $0.73 \%$ ) as per SOC ranking outlined in FRG-2005 (BARC, 2005). It was observed that the SOC content (\%) decreased with increasing of soil depths irrespective of land types (Fig. $1 \mathrm{~B}$ ). However, the sOC content (\%) in low land was higher than that in high and medium high lands.

\section{AEZ 4: Karatoya-Bangali Floodplain}

The SOC content (\%) in high land was medium to very low $(1.12 \%$ to $0.39 \%)$, in medium high land it was medium to very low (1.08\% to $0.26 \%$ ) and in low land was low to very low ( $0.96 \%$ to $0.35 \%)$, as per SOC ranking outlined in FRG-2005 (BARC, 2005). It was observed that the SOC content (\%) decreased with increasing of soil depths irrespective of land types (Fig. 1C). However, the sOC content (\%) in high land was higher than that in medium high land and low land.

\section{AEZ 9: Old Brahmaputra Floodplain}

The SOC content (\%) in high land was medium to very low (1.37\% to $0.40 \%)$, in medium high land it was medium to very low (1.59\% to $0.45 \%)$ and in low land it was high to low (2.30\% to $0.90 \%$ ), as per SOC ranking outlined in FRG2005 (BARC, 2005). It was observed that the SOC content (\%) decreased with increasing of soil depths irrespective of land types (Fig. 1 D). However, the SOC content (\%) in low land was higher than that in high and medium high lands. 

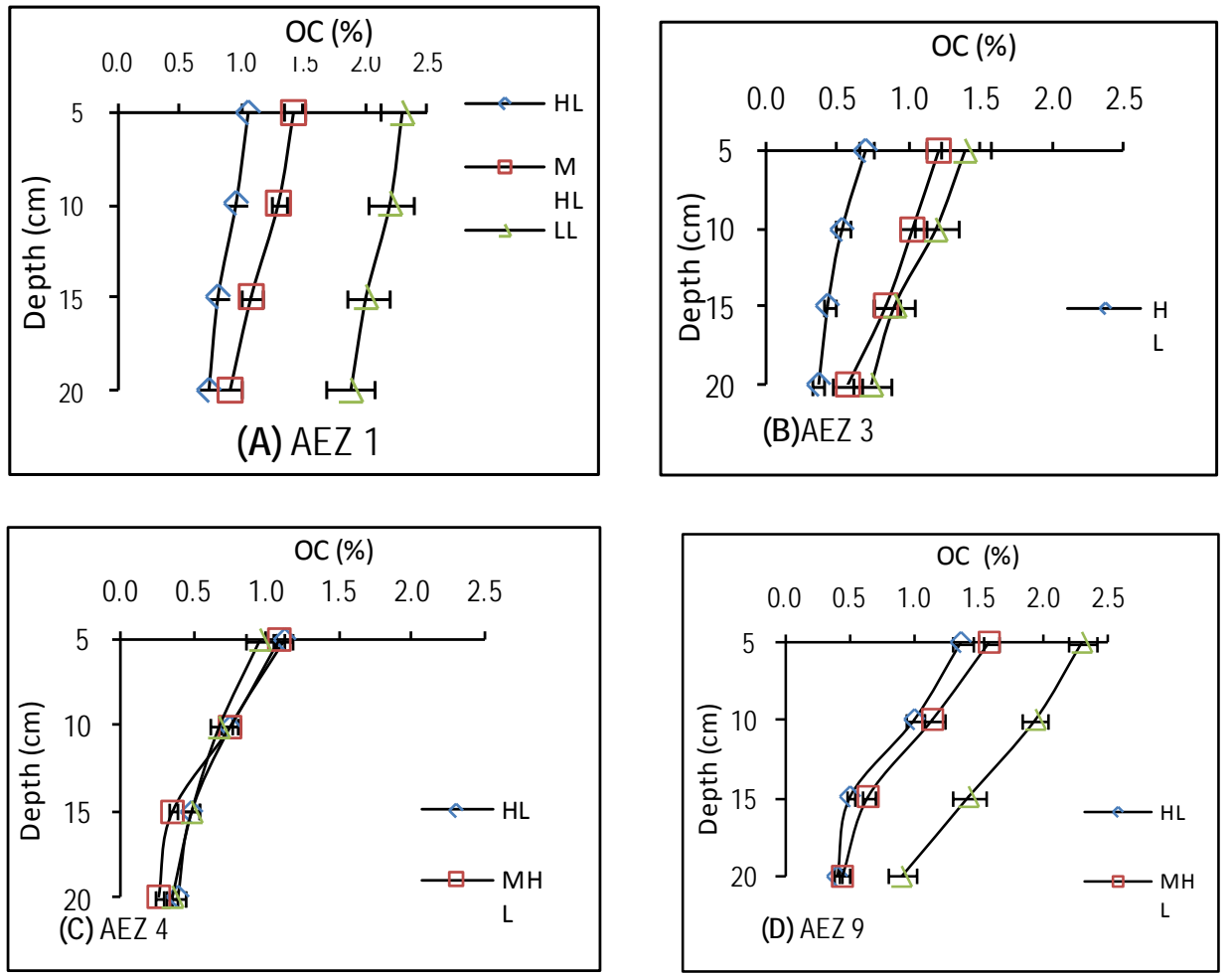

Fig. 1. SOC content (\%) at different depths of soils in four AEZs.

In low land areas, only boro rice was grown and in high and medium high lands T.Aman and rabi crops were grown. It indicates that tillage operation was more in high and medium high lands and less in low land. It is recognized that organic matter decomposition is faster under frequent tillage operations (Gebhart et al., 1994) and further in low land top soils with organic debris are deposited through surface run off the soil undergoes submergence for a longer period, under the situation the OM decomposition is not active due to anaerobic situation.

\section{Soil organic carbon (SOC) stock}

\section{AEZ 1. Old Himalayan Piedmont Plain}

There were mainly three land types in AEZ 1 viz., high land, medium high land and low land. The average SOC stocks of the land types were 7.13 to 5.50, 8.79 to 7.51 and 15.88 to $13.06 \mathrm{t} /$ ha, respectively (Fig. 2 A). The highest SOC stock was observed in low land and the lowest in high land. It appeared that the SOC stock increased up to $10 \mathrm{~cm}$ soil depth in high land and low land and then decreased with the increase of soil depth, while in medium high land the trend was 
different. The highest SOC stock (8.79 t/ha) was found in 0 to $5 \mathrm{~cm}$ depth and the lowest (7.51 t/ha) in 15 to $20 \mathrm{~cm}$ depth.

\section{AEZ 3. Tista Meander Floodplain}

The average SOC stocks of the land types viz., high land, medium high land, and low land were 4.35 to $2.51,7.11$ to 4.44 , and 7.21 to 5.31 t/ha, respectively (Fig. $2 \mathrm{~B}$ ). The highest SOC stock was observed in low land and the lowest was in high land. It appeared that the SOC stock increased up to $10 \mathrm{~cm}$ soil depth in medium high land and low land and then decreased with the increase of soil depth while in high land the trend was different. The highest SOC stock (4.35 t/ha) was found in 0 to $5 \mathrm{~cm}$ depth and the lowest (2.51 t/ha) was in 15 to $20 \mathrm{~cm}$ depth (Fig. 2B).

\section{AEZ 4. Karatoya-Bangali Flood Plain}

The average SOC stocks of the land types viz., high land, medium high land and low land were 6.00 to $3.03,8.10$ to 2.08 and 7.24 to 2.66 t/ha, respectively (Fig. 2 C). At 0-5 cm layer, the highest SOC stock was observed in medium high land and the lowest in high land. It appeared that the SOC stock decreased gradually with the increase of soil depth irrespective of land types.
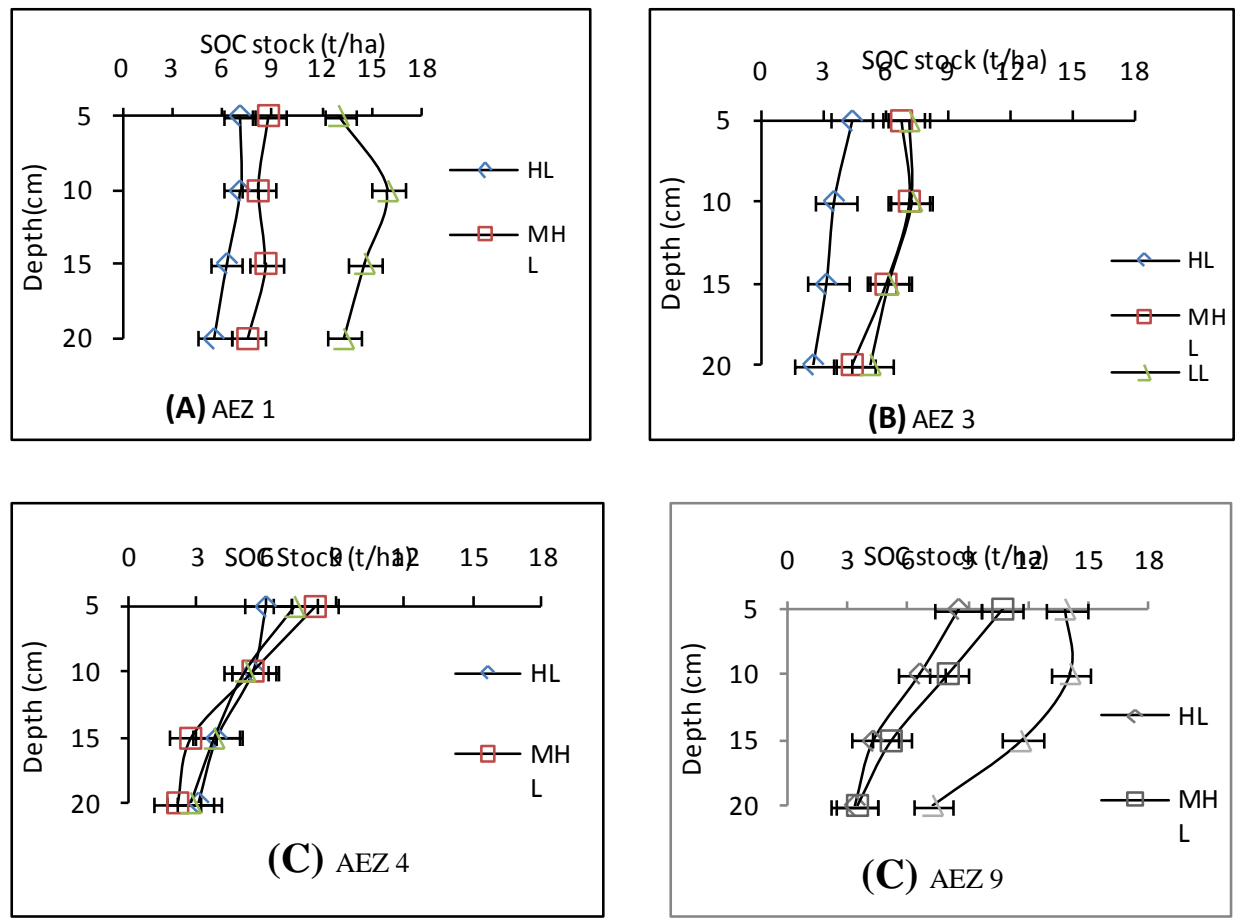

Fig. 2. SOC stock (t/ha) at different depth of soils in four AEZs. 


\section{AEZ 9. Old Brahmaputra Floodplain}

The average SOC stocks of the land types viz., high land, medium high land and low land were 8.46 to $3.29,10.67$ to 3.41 and 14.07 to 7.22 t/ha, respectively (Fig. 2 D). The highest SOC stock was observed in low land and the lowest in high land. It appeared that the SOC stock increased up to $10 \mathrm{~cm}$ soil depth in low land and then decreased with the increase of soil depth, while in high and medium high lands, the SOC stock decreased with the increase of soil depth. The highest SOC stock (14.07 t/ha) was found in 5 to $10 \mathrm{~cm}$ depth in low land and the lowest (3.29 t/ha) in 15 to $20 \mathrm{~cm}$ depth in high land.

\section{Average SOC content and SOC stock}

\section{AEZ 1. Old Himalayan Piedmont Plain}

Over the $0-20 \mathrm{~cm}$ soil depth, the highest amount of SOC content (2.10\%) was found in low land and the lowest amount (0.89\%) in high land (Table 2). Similar trend was observed in case of SOC stock. It varied from $14.19(\mathrm{t} / \mathrm{ha})$ in low land to 6.46 (t/ha) in high land.

\section{AEZ 3. Tista Meander Floodplain}

Table 2 indicates that the highest amount of SOC content (1.05\%) was in low land and the lowest amount (0.50\%) in high land over the $0-20 \mathrm{~cm}$ soil depth. Similar trend was noticed in case of SOC stock. It ranged from $6.45(\mathrm{t} / \mathrm{ha})$ in low land to 3.39 (t/ha) in high land.

Table 2. Average SOC content and SOC stock in different AEZs.

\begin{tabular}{c|c|c|c|c|c|c}
\hline \multirow{2}{*}{ AEZ } & \multicolumn{3}{|c|}{ SOC content (\%) } & \multicolumn{3}{c}{ SOC stock (t/ha) } \\
\cline { 2 - 7 } & HL & MHL & LL & HL & MHL & LL \\
\hline 1 & $0.89 \pm 0.09$ & $1.17 \pm 0.08$ & $2.10 \pm 0.19$ & $6.46 \pm 0.66$ & $8.25 \pm 0.62$ & $14.19 \pm 1.29$ \\
3 & $0.50 \pm 0.05$ & $0.90 \pm 0.09$ & $1.05 \pm 0.15$ & $3.39 \pm 0.33$ & $6.09 \pm 0.74$ & $6.45 \pm 1.00$ \\
4 & $0.69 \pm 0.05$ & $0.61 \pm 0.04$ & $0.62 \pm 0.07$ & $4.58 \pm 0.35$ & $4.58 \pm 0.33$ & $4.67 \pm 0.53$ \\
9 & $0.82 \pm 0.05$ & $0.96 \pm 0.05$ & $1.64 \pm 0.11$ & $5.65 \pm 0.42$ & $6.81 \pm 0.38$ & $11.71 \pm 0.90$ \\
\hline
\end{tabular}

\section{AEZ 4. Karatoya-Bangali Flood Plain}

Over the $0-20 \mathrm{~cm}$ soil depth the highest amount of SOC content (0.69\%) was found in high land and the lowest amount $(0.61 \%)$ in medium high land (Table 2) and the trend was different in case of SOC stock. It ranged from $4.67(\mathrm{t} / \mathrm{ha})$ in low land to 4.58 (t/ha) in medium high land and high lands. 


\section{AEZ 9. Old Brahmaputra Flood Plain}

Table 2 shows that the highest amount of SOC content (1.64\%) in low land and the lowest amount $(0.82 \%)$ in high land over the $0-20 \mathrm{~cm}$ soil depth. Similar trend was also observed in case of SOC stock, ranged from 11.71 (t/ha) in low land to 5.65 (t/ha) in high land.

\section{Bulk density}

\section{AEZ 1. Old Himalayan Piedmont Plain}

Bulk density of medium high land varied from 1.26 to $1.67 \mathrm{~g} / \mathrm{cc}$, in high land from 1.33 to $1.55 \mathrm{~g} / \mathrm{cc}$ and for low land, it was 1.13 to $1.44 \mathrm{~g} / \mathrm{cc}$ (Table 3). Medium high lands were more compact at10-15 cm and 15-20 cm soil layer than other land types. With the increase of soil depth bulk density increased more distinctly in medium high land than in high land and low land. The lowest bulk density was found in low land because of higher moisture content and flocculent soft layer in the top soils of low land which contributed to less dry mass compared to medium high land and high land.

\section{AEZ 3. Tista Meander Floodplain}

Bulk density of medium high land varied from 1.12 to $1.57 \mathrm{~g} / \mathrm{cc}$, in high land from 1.23 to $1.48 \mathrm{~g} / \mathrm{cc}$ and for low land, it was 1.01 to $1.46 \mathrm{~g} / \mathrm{cc}$ (Table 3). Medium high lands were more compact at $10-15 \mathrm{~cm}$ and $15-20 \mathrm{~cm}$ soil layer than other land types. With the increase of soil depth bulk density increased more distinctly in high and medium high lands than in low land. The lowest bulk density was found in low land because of higher moisture content and flocculent soft layer in the top soils of low land which contributed to less dry mass compared to medium high land and high land.

\section{AEZ 4. Karatoya-Bangali Flood Plain}

Bulk density of high land varied from 1.10 to $1.65 \mathrm{~g} / \mathrm{cc}$, in medium high land from 1.46 to $1.58 \mathrm{~g} / \mathrm{cc}$ and for low land, it was 1.49 to $1.61 \mathrm{~g} / \mathrm{cc}$ (Table 3). In all land types, at $10-15 \mathrm{~cm}$ and $15-20 \mathrm{~cm}$ soil layer bulk density was higher than that of $0-5 \mathrm{~cm}$ and 5-10 $\mathrm{cm}$ layer. It indicates that lower soil layers were comparatively compact than upper layer. 
Table 3. Bulk density (g/cc) of soils at different depths in different AEZs.

\begin{tabular}{|c|c|c|c|c|c|c|c|c|c|c|c|c|}
\hline \multirow{3}{*}{$\begin{array}{l}\mathrm{A} \\
\mathrm{E} \\
\mathrm{Z}\end{array}$} & \multicolumn{12}{|c|}{ Land type/depth (cm) } \\
\hline & \multicolumn{4}{|c|}{ HL } & \multicolumn{4}{|c|}{ MHL } & \multicolumn{4}{|c|}{ LL } \\
\hline & 00-05 & $05-10$ & $10-15$ & $15-20$ & 00-05 & $05-10$ & $10-15$ & $15-20$ & 00-05 & $05-10$ & $10-15$ & $15-20$ \\
\hline 1 & $1.33 \pm .05$ & $1.50 \pm .02$ & $1.55 \pm .03$ & $1.49 \pm .02$ & $1.29 \pm .08$ & $1.26 \pm .01$ & $1.60 \pm .04$ & $1.67 \pm .03$ & $1.13 \pm .02$ & $1.43 \pm .04$ & $1.44 \pm .02$ & $1.43 \pm .04$ \\
\hline 3 & $1.23 \pm .12$ & $1.35 \pm .02$ & $1.48 \pm .06$ & $1.47 \pm .14$ & $1.12 \pm .05$ & $1.35 \pm .27$ & $1.42 \pm .20$ & $1.57 \pm .00$ & $1.01 \pm .11$ & $1.18 \pm .16$ & $1.37 \pm .03$ & $1.46 \pm .07$ \\
\hline 4 & $1.10 \pm .10$ & $1.48 \pm .11$ & $1.65 \pm .05$ & $1.54 \pm .02$ & $1.48 \pm .11$ & $1.46 \pm .01$ & $1.57 \pm .06$ & $1.58 \pm .08$ & $1.53 \pm .09$ & $1.49 \pm .08$ & $1.61 \pm .08$ & $1.53 \pm .02$ \\
\hline 9 & $1.23 \pm .03$ & $1.36 \pm .01$ & $1.58 \pm .13$ & $1.62 \pm .06$ & $1.35 \pm .16$ & $1.41 \pm .12$ & $1.58 \pm .04$ & $1.50 \pm .08$ & $1.20 \pm .06$ & $1.44 \pm .06$ & $1.63 \pm .03$ & $1.58 \pm .05$ \\
\hline
\end{tabular}




\section{AEZ 9. Old Brahmaputra Flood Plain}

Bulk density of medium high land varied from 1.35 to $1.58 \mathrm{~g} / \mathrm{cc}$, in high land from 1.23 to $1.62 \mathrm{~g} / \mathrm{cc}$ and for low land, it was 1.20 to $1.63 \mathrm{~g} / \mathrm{cc}$ (Table 3). Medium high lands were more compact at 0-5 cm and 5-10 cm soil layer than other land types. With the increase of soil depth, bulk density increased more distinctly in medium high land and low land than in high land up to $10-15 \mathrm{~cm}$ and then decreased. The lowest bulk density was found in low land because of higher moisture content and flocculent soft layer in the top soils of low land which contributed to less dry mass compared to medium high land and high land.

\section{Conclusion}

The soil organic carbon SOC (\%) decreased with the increase in soil depth irrespective of land types. The SOC (\%) was found higher in the low land than in the medium high land and high land. Bulk density tended to increase with increasing soil depth with certain deviation. Bulk density of medium high land varied from 1.26 to $1.67 \mathrm{~g} / \mathrm{cc}$, whereas in high land and low land, it varied from $1.33-1.55 \mathrm{~g} / \mathrm{cc}$ and 1.13-1.44 g/cc, respectively. The SOC stock (t/ha) at 0-20 cm depth was higher in low land compared to medium high land and high land soil in irrespective of AEZs. Among the four AEZs, the highest SOC stock ( $t /$ ha) was found in AEZ-1 irrespective of land types.

\section{Acknowledgements}

The authors gratefully acknowledge the PIU-BARC, NATP for providing financial assistance for supporting this research. Thank to the Bangladesh Rice Research Institute authority for providing the research sites and help in conducting the research.

\section{References}

BARC. 2005. Fertilizer Recommendation Guide-2005. Bangladesh Agricultural Research Council (BARC), Farmgate, New Airport Road, Dhaka-1215, 260p.

Blake, G. R. and K. H. Hartge. 1986. Methods of Soil Analysis, Part 1. Physical and Mineralogical Methods. Agronomy Monograph No. 9: 363-375.

Cole, C.V., K. Flach, J. Lee, D. Sauerbeck and B. Stewart.1993. Agricultural sources and sinks of carbon. Water, Air and Soil Pollution 70:111-122.

Gebhart, D. L., H. B. Johson, H. S. Mayeux and H. W. Polley. 1994. The CRP increases soil organic carbon. J. Soil Water Conserv. 49: 488-492.

Kong, A.Y.Y., J. Six, D.C. Bryant, R.F. Denison and C. Van Kessel. 2005. The relationship between carbon input, aggregation and soil organic carbon stabilization in sustainable cropping systems. Soil Science Society of America Journal 69:1078-1085.

Lal, R. 2004. Soil carbon sequestration to mitigate climate change. Geoderma 123:1-22. 
Komatsuzaki, M. and M. F. Syuaib. 2009. A case study of organic rice production system and soil carbon Storage in West Java, Indonesia. Japanese J. of Farm Work Res. 44 (3): 173-179.

Reicosky, D. C. and M. J. Lindstorm. 1993. Fall tillage method: Effect on short-term carbon dioxide flux from soil. Agron. J. 85(6): 1237-1243.

Walkley, A. and I. A. Black. 1934. An examination of degtjareff method for determining soil organic matter and a proposed modification of the chromic acid titration method. Soil Sci. 37:29-37. 